\title{
Psychological and Biographical Determinants of Entrepreneurial Intention: Does the Learning Environment Act as a Mediator?
}

\author{
Mateo M. Córcoles-Muñoz ${ }^{\mathbb{D}}$, Gloria Parra-Requena, María José Ruiz-Ortega *(D), \\ Pedro M. García-Villaverde and Francisco J. Ramírez-Fernández
}

Department of Business Administration, University of Castilla-La Mancha, 02005 Albacete, Spain; mateom.corcoles@uclm.es (M.M.C.-M.); gloria.parra@uclm.es (G.P.-R.); pedro.gvillaverde@uclm.es (P.M.G.-V.); FranciscoJ.Ramirez@uclm.es (F.J.R.-F.)

* Correspondence: mariajose.ruiz@uclm.es

Received: 28 February 2019; Accepted: 6 April 2019; Published: 9 April 2019

\begin{abstract}
The aim of this research is to study the mediating role of the learning process in explaining the relationships between certain psychological and biographical characteristics and entrepreneurial intention. The findings suggest that the effect of psychological and biographical aspects on entrepreneurial intention depend on the extent to which students are able to take advantage of their personal capabilities in order to develop an effective learning process. Learning process factors (information about course guides, student effort and educational processes) mediate the relationships between specific psychological factors (achievement need, internal control and autonomy) and entrepreneurial intention. With regard to biographical factors, we find no mediating effect on entrepreneurial intention through the learning process. The present study provides a better understanding of the antecedents of entrepreneurial intention, helping to fill the gap in the literature.
\end{abstract}

Keywords: entrepreneurial intention; learning process; entrepreneurial education; psychological factors; biographical factors; mediating model

\section{Introduction}

According to the Central Business Register (INE 2018), in August 2018, small and medium-sized enterprises (SMEs) made up $99.80 \%$ of the Spanish industrial fabric. In other words, out of a total of 2,870,935 companies, only 4473 were considered large companies. In addition, these SMEs employed a total of $8,277,215$ workers compared to $5,173,179$ for large companies, that is, $53.5 \%$ of workers in Spain were employed in SMEs, 33.5\% in large companies and the remaining 13\% corresponded to self-employed workers without dependent employees. Faced by a business structure with a clear predominance of small businesses and self-employed workers in most countries, entrepreneurs are gaining significant importance as they are able to generate new jobs and contribute to the growth and modernization of the economy (Carlsson et al. 2013). In this sense, entrepreneurship is a key factor for economic growth, the generation of new jobs, increased innovation and improved productivity in countries (Türker and Sonmez 2009; Gómez-Gras et al. 2010; Keat et al. 2011; Urbano and Aparicio 2015). This key role of entrepreneurship has generated a growing interest in areas such as politics, economics, psychology, management and cognitive aspects since the last decades of the past century (Kuttim et al. 2014).

Entrepreneurship has been considered the process of seeking, evaluating and subsequently exploiting opportunities in markets, and entrepreneur refers to the person who performs this process (Shane and Venkataraman 2000). Van Gelderen et al. (2008) defined entrepreneurship as an attitude 
based on two aspects: The intention and the capacity of an individual to search, identify and take advantage of an opportunity. Thus, before a person can be an entrepreneur, they must firstly be a potential entrepreneur (Krueger and Brazeal 1994), that is, they must have a strong intention of being an entrepreneur. According to social psychology, intention is the best predictor of a planned behaviour (Brito et al. 2014), so entrepreneurial intention, understood as the mental state of a person focused on the creation of a new business (Prodan and Drnovsek 2010), represents the best predictor of becoming an entrepreneur in the future (Kautonen et al. 2015). In conclusion, by acting as the first step in creating a company, entrepreneurial intention represents a key element in understanding the process of entrepreneurship (Lee and Wong 2004). Hence, the study of entrepreneurship in the economic literature has grown exponentially in recent years (Kuttim et al. 2014; Arias et al. 2015).

Several works have studied the factors that affect entrepreneurial intention (e.g., De Pillis and Reardon 2007; Liñán et al. 2011; Antonioli et al. 2016; Barba-Sánchez and Atienza-Sahuquillo 2017; among others). However, entrepreneurial intention is a multi-causal phenomenon that has not been explored in its entirety; further research is required to better understand the causes. Traditionally, the main reason for starting a business has been considered to be economic interest (Carsrud and Brännback 2009). However, recent studies highlight the existence of other reasons (Hatak et al. 2015). Mazzarol et al. (1999) emphasize that entrepreneurship can be studied by focusing on individuals' internal factors, such as their personal characteristics, specific features, such as personality and human capital, or exogenous factors, such as the general environment, the culture, the political system and economic growth.

In line with the above, entrepreneurial intention may emerge due to psychological, sociological or environmental reasons. In the case of environmental factors, unemployment stands out as a key contextual determinant of entrepreneurial intention (Kautonen and Palmroos 2010). The internal characteristics of individuals have also been widely recognised as predictors of entrepreneurial intention (Ciavarella et al. 2004). Ashley-Cotleur et al. (2009) highlight, in particular, the psychological and biographical factors. Regarding psychological factors, Harris et al. (2007) underline their influence in the likelihood of a person creating a company. Biographical factors, which are linked to aspects such as age or gender, also influence the determination of entrepreneurial intention (Toledo-Nickels 2001). Despite the numerous contributions in the literature on entrepreneurship, several authors point out that the discussion about the internal factors with the greatest impact on entrepreneurial intention is still open. Several studies demand this gap be filled (Arias et al. 2015). Furthermore, the mechanisms that link these individual factors to greater entrepreneurial intention are still not fully understood (Van Gelderen et al. 2008; Barba-Sánchez and Atienza-Sahuquillo 2017). There is a gap, then, that encourages us to delve into how acquired and perceived skills of business undertaking can connect the personal traits of individuals with their entrepreneurial intention (Mueller 2011).

In order to respond to these gaps in the literature, we propose two research lines in this study. First, it is necessary to analyse the explanatory value of various psychological and biographical factors in understanding entrepreneurial intention, in line with the approaches of various studies (De Pillis and Reardon 2007; Liñán et al. 2011; De la Rosa et al. 2014; among others). Specifically, of the psychological characteristics, we study achievement need, autonomy, internal control and optimism; and, of the biographical features, we analyse the influence of age, previous work experience, gender and university access grades. Second, it is necessary to understand how the process of acquiring entrepreneurial skills can drive individuals with certain characteristics towards entrepreneurship.

Given the relevance of entrepreneurship for the economic, employment and social development of countries, many governments consider entrepreneurial education a key factor in the channelling of support resources for entrepreneurship (Altinay et al. 2012). This governmental support for entrepreneurship education is based on two general ideas: First, entrepreneurship is not only innate, and can be learned and transmitted through learning processes (Harkema and Schout 2008), and second, education in entrepreneurship is a determinant of entrepreneurial intention (Türker and Sonmez 2009; Lima et al. 2015; Musteen et al. 2018; among others). Thus, a greater number of 
academic business-related subjects increase and reinforce the intention to create a company in the future. Consequently, from the first entrepreneurship courses developed in the 1950s to the present, there has been a great increase in actions related to entrepreneurial education. Universities are responsible for offering education in entrepreneurship that is of quality and that is adjusted to market needs, which allows students to improve their knowledge and entrepreneurial intention. From this approach, several authors have pointed out that a key problem to be solved is the design of an adequate learning process to motivate students for entrepreneurship (Auken 2013). Thus, it is necessary to develop new pedagogical strategies that allow students to acquire business skills and increase their entrepreneurial intention (Liñan and Fayolle 2015). In contrast to the widely accepted positive relationship between education in entrepreneurship and entrepreneurial intention (Lorz et al. 2011), in recent years, several works have appeared with contradictory results (Oosterbeek et al. 2010; Fayolle and Gailly 2013; among others). New research is then required to delve deeper into the role of the learning process in entrepreneurial intention.

The aim of this study is to respond to this demand, analysing the role in entrepreneurship education of the learning process in driving the personal characteristics-psychological and biographical—of students towards greater entrepreneurial intention. To this end, we analyse key elements of the learning process, such as the information provided on the course, the effort students make and the educational process. To address this goal, on the one hand, we analyse the role of psychological factors (achievement need, internal control, optimism and autonomy) and biographical characteristics (age, work experience, gender and the university access grades) in entrepreneurial intention, in order to detect the explanatory capacity of each one. On the other hand, we study the mediating effect of the learning process in the relationship between personal factors and entrepreneurial intention. With this new approach, we intend to contribute to the literature by explaining how the learning process must be oriented towards taking advantage of the potential of university students, and the value of entrepreneurial education in the university through the subjects related to entrepreneurship.

To develop this work, we analysed a sample of 167 students of entrepreneurship in the fourth and final year of the Degree in Labour Relations and Human Resources at the University of Castilla-La Mancha between 2012 and 2018. This sample is suitable for studying entrepreneurial intention (Bae et al. 2014), since university students in the final year must make decisions on their professional life, and those enrolled in entrepreneurship courses are considered a population of potential entrepreneurs (Sánchez et al. 2005). In sum, it is especially interesting to analyse the personal factors of students that influence entrepreneurial intention, as well as the role of the learning process in entrepreneurship in instilling greater entrepreneurial intention.

This work is structured as follows: First, the theory and hypotheses are explained, followed by a description of the methodology. Subsequently, the results are presented. Finally, the discussion, conclusions, recommendations, limitations and future research proposals are established.

\section{Theoretical Backgrounds to Entrepreneurial Intention and Hypotheses}

\subsection{Entrepreneurial Intention}

Entrepreneurship has generated great interest in recent decades in different fields of study due to its importance for the economic development of countries (Türker and Sonmez 2009; Keat et al. 2011; Kuttim et al. 2014; Urbano and Aparicio 2015). Within the study of entrepreneurship, different lines of research have emerged, among which entrepreneurial intention (Arias et al. 2015) stands out in recent years due to the need to understand its background and to promote the development of entrepreneurial projects.

The concept of intention originated in cognitive psychology to explain or try to predict human behaviour (Fatoki 2010). Ajzen (1987) established that intention could predict behaviour. For Gibbs (2004), intention is the psychological state of a person linked to a plan to try to achieve a 
reachable goal. Therefore, intention represents the determination or commitment to performing a certain action. Hence, it is configured as the best predictor of a planned behaviour, especially when it is rare or difficult to observe, such as in the case of entrepreneurship (Brito et al. 2014).

Entrepreneurship is considered an intentional activity (Henley 2007), based on two aspects: The intention, and the capacity of an individual to search, identify and take advantage of an opportunity (Van Gelderen et al. 2008). In this way, before a person becomes an entrepreneur, they must first be a potential entrepreneur (Krueger and Brazeal 1994). Moreover, people with entrepreneurial intention tend to adopt a rational behaviour to create a new business (Fatoki 2010), generating predisposition as the foundation for the creation of new companies. In this sense, entrepreneurial intention, understood as the mental state of a person focused on the creation of a company (Prodan and Drnovsek 2010), helps to understand the process of entrepreneurship (Lee and Wong 2004), being configured as one of its key predictors (Kautonen et al. 2015). As is emphasized in the extensive literature on this topic, entrepreneurial intention is affected by several factors, among which we identify those linked to psychological and biographical aspects.

\subsection{Personal Backgrounds. The Psychological and Biographical Factors}

The antecedents of the intention and the action to be undertaken are very varied. The literature distinguishes between factors linked to the birth of a "pull" opportunity or a "push" need (Verheul et al. 2016). The literature recognises the opportunity when the individual considers the creation of a company as a reason to obtain monetary benefits (higher level of incomes), for psychological aspects (autonomy, self-realization, independence, etc.), or the need to become self-employed because the market labour does not meet their demands (unemployment, dissatisfaction, etc.). In the same way, entrepreneurial intention may be due to the internal characteristics of the individual or his environment (Mazzarol et al. 1999). Thus, compared to the traditional conception of business creation for economic reasons (Carsrud and Brännback 2009), we find other justifications that introduce psychological, social and contextual factors as antecedents of entrepreneurial intention.

Research works in the literature have demonstrated that the contextual factors of an individual-political, economic, cultural, technological, etc.-influence entrepreneurial intention. In this sense, Kautonen and Palmroos (2010) showed that high levels of unemployment tend to encourage entrepreneurship. De Pillis and Reardon (2007) verified, after analysing cultural features of the United States and Ireland, that a country's culture of entrepreneurship influences the tendency of individuals to create a new company.

In this work, we focus on the personal antecedents of entrepreneurial intention (Ciavarella et al. 2004). Despite the criticisms of the consideration of these internal factors as unreliable indicators compared with other explanatory models (Arias et al. 2015), several studies have highlighted that the characteristics of individuals have a greater explanatory influence on entrepreneurial intention than economic and contextual factors (Ilouga et al. 2014). This discussion leads us to focus on the analysis of the characteristics of individuals as antecedents of entrepreneurial intention.

According to Ashley-Cotleur et al. (2009), certain individual factors influence the decision to start a business, and can be grouped into two types (Fatoki 2010): Psychological and demographic. In the last decade, psychological characteristics (Espiritu-Olmos and Sastre-Castillo 2015), and biographical features have received great attention, including, among others, gender (Davidsson 1995; De la Rosa et al. 2014), age (Martínez and Milone 2016) or work experience (Loli et al. 2010).

Psychological traits have been widely used in the entrepreneurship literature. In this line, Harris et al. (2007) established that personality characteristics influence the probability of a person creating a new business. Espíritu Olmos (2011) also states that certain psychological features are associated with an entrepreneur. From the social psychology approach, psychological characteristics are linked to attitudes, which were defined by Fishbein and Ajzen (1975) as a predisposition to respond favourably or unfavourably in time with respect to a certain object. This attitude is a predictor of people's behaviour in aspects such as entrepreneurship. 
The Theory of Personality Traits, which appeared in the 1960s with the work by McClelland (1961), is a first approach by the field of psychology to the study of entrepreneurship. According to this author, the personality traits of an individual are necessary to create a company, thus differentiating entrepreneurs from the rest of the population. Obschonka et al. (2010) proposed a personality pattern for entrepreneurs, establishing that individuals with similar characteristics to those proposed in their work, showed greater entrepreneurial intention. However, several authors suggest there is no single psychological profile of entrepreneurs (Marulanda et al. 2009), and thus further research is required. Hence, we focus on the most relevant psychological traits addressed in the entrepreneurship literature, as follows:

- $\quad$ Achievement need: This can be understood as a strong need to achieve objectives, goals and proposed tasks through great efforts (Arias et al. 2015). McClelland (1961) considers this feature predisposes people to performing exceptional activities as a measure of achievement. In addition, he considers it is related to the desire to solve problems and achieve priority objectives, assuming moderate risks after the evaluation of the alternatives and the need to receive feedback to measure their success. This feature has been widely studied in the literature on entrepreneurship, and several authors have highlighted its influence on entrepreneurial intention (Sánchez et al. 2005; Mai and Anh 2013; Sánchez et al. 2005; Soomro and Shah 2015).

- Internal control: Internal control, or locus of control, refers to the belief that the things that happen in life are due to the actions of individuals. Therefore, it refers to a person's expectation of controlling everything that happens in their life (Mokhtar and Zainuddin 2011). People with a high locus of control consider that results in their lives are a consequence of their own actions. In contrast, a person with a low locus of control considers that everything that happens in their life is due to factors beyond their control, such as luck (De Pillis and Reardon 2007). Internal control has been linked with entrepreneurship in some research works (Gatewood et al. 1995). Ajzen (1991), for example, points out that internal control is necessary for a person to make decisions about the risks taken to create a new company.

- Optimism: This is the attitude an individual presents regarding an event in their life. An optimistic person tends to stay positive in the face of future expectations, whereas a pessimistic person tends to remain negative in the face of future expectations (Scheier et al. 1994). Due to its characteristics, entrepreneurship is a complex and risky activity. In this case, optimistic people will pay more attention to opportunities than risks or difficulties. Thus, González and Valdez (2012) consider that the optimistic orientation of a person leads them to experience positive feelings in the face of difficulties by helping them in complex activities such as entrepreneurship. Similarly, Loli et al. (2010) point out that optimism is a characteristic of people with entrepreneurial intention.

- Autonomy: This is a feature that allows an individual to act according to their own criteria, independently of the opinion of third parties. This independence when acting is linked to the possibility of carrying out one's own ideas (Sánchez et al. 2005). Entrepreneurship allows a person to define their life, their objectives and how or when they do things (Hessels et al. 2008). Several works have found that the main reason for creating a new business is a person's need for autonomy (Fatoki 2010). In particular, Martínez and Milone (2016) found that the most important reason to create one's own company is the non-dependence on a superior.

Biographical factors, linked to an individual's circumstances, have received great attention in the last decade in the study of the background to entrepreneurial intention (Loli et al. 2010; Brito et al. 2014; Phipps and Prieto 2015; Martínez and Milone 2016). Of the different biographical factors presented in an individual, the literature highlights age and gender as two basic factors that usually affect people's behaviour. In addition, we incorporate two complementary factors-university access grades and professional trajectory-work experience-linked to the educational trajectory of potential entrepreneurs. In this work, therefore, we analyse the following: 
- $\quad$ Age: A large body of literature has underlined that younger people have a greater entrepreneurial intention compared to older individuals (Davidsson 1995; Obschonka et al. 2010; Martínez and Milone 2016).

- Work experience: A person's previous work experience favours the development of greater entrepreneurial intention (Loli et al. 2010; Martínez and Milone 2016). However, for Brito et al. (2014), work experience does not directly influence entrepreneurial intention but acts indirectly on it, through other factors, such as desirability or perceived easiness.

- $\quad$ Gender: The study of gender in entrepreneurial intention began in the 1980s and continues today (Ventura Fernández and Gervilla 2013). The results obtained in different studies show that gender has an influence on entrepreneurial intention. Specifically, authors have found a greater entrepreneurial intention in men compared to women (Davidsson 1995; Brito et al. 2014; Martínez and Milone 2016).

- University access grades: In this case, the overall grades achieved by students to access university studies are analysed in order to observe their influence on entrepreneurial intention. Previous studies, such as that by Happ et al. (2016), measured the grades obtained by students at high school, correlating them with the learning outcomes in introductory economics courses at university.

In summary, the aforementioned arguments allow us to hypothesize that certain psychological traits-achievement need, internal control, optimism and autonomy — and biographical factors-age, work experience, gender and university access grades-positively influence entrepreneurial intention. Therefore, we formulate the following hypotheses:

Hypothesis 1. Psychological factors (achievement need, internal control, optimism and autonomy) have a positive effect on students' entrepreneurial intention.

Hypothesis 2. Biographical factors (age, work experience, gender and university access grades) have a positive effect on students' entrepreneurial intention.

\subsection{The Role of the Learning Process}

Entrepreneurship is not something uniquely innate. It can be learned and transmitted through learning processes (Harkema and Schout 2008). Several studies have shown that entrepreneurship education positively affects an individual's entrepreneurial intention (Türker and Sonmez 2009; Mueller 2011; Lima et al. 2015; among others). Based on these premises, actions in entrepreneurship education have increased exponentially since the first entrepreneurship courses in the middle of the last century. Governments and public and private institutions have driven these actions, investing in resources to support entrepreneurship as a source to generate economic growth and employment, (Altinay et al. 2012). In Spain, this support from institutions is enshrined in Law 14/2013 on Support for Entrepreneurship and Its Internationalization ${ }^{1}$, which highlights the need to implement education in entrepreneurship from primary to university education, including vocational training. The aim is to provide students with the necessary skills to undertake and support an entrepreneurial initiative, in accordance with other European Union guidelines. In addition, with the implementation of the Bologna Process, European universities have introduced new educational actions, such as teaching through projects, teamwork, autonomy, creativity, etc., to more actively encourage entrepreneurship among students (Freire 2015). In sum, higher education in all fields of knowledge has acquired great relevance for the development of business skills (González Moreno et al. 2019), and to encourage entrepreneurial intention. Therefore, academic institutions, especially universities, have the obligation

1 Law No. 233 on Support for Entrepreneurs and their Internationalization. Official State Gazette, Spain, September 28, 2013. 
to provide education in entrepreneurship of quality, adjusted to market needs, allowing students to improve their knowledge and business skills, as well as their entrepreneurial intention. In this sense, the design of an adequate learning process that motivates students for entrepreneurship (Auken 2013) is a key aspect.

Pintrich (1994), one of the most famous researchers in educational psychology, published an interesting work on research trends in education. This author invites readers to think about the knowledge acquired up to that moment, and then to try to develop an integrated theoretical model. Until that time, most of the research on learning in schools had focused on separate variables and there was little research into the interaction between the components of entrepreneurial intention (Valle et al. 2003). A person's learning process is affected by the interaction between their personal and contextual characteristics. Some authors point out the influence of both types of characteristics (Richter 1998), while others, on the other hand, emphasize the importance of personal characteristics (Ashford and Black 1996). In this paper, we focus special attention on the role of personal traits (psychological and biographical) of students in the learning process, in line with previous research (Fine-Davis and Faas 2014; Happ et al. 2016; among others). Several authors have indicated that psychological factors can affect the ability to learn (Fine-Davis and Faas 2014). Brückner et al. (2015) also highlight that biographical factors affect learning in economics subjects.

In line with the above, Valle et al. (2003) found a positive relation between certain personal factors and learning. Other authors such as Schunk and Pajares (2004) have focused on the role that student self-efficacy has on entrepreneurial intention. A recent work addressed the relationship between personality traits and entrepreneurial intention, demonstrating direct and indirect relationships between personality and coping and adjustment, and linking certain personality factors with achievement during a typical stressful education process (Perera et al. 2015). Other authors who have analysed the influence of biographical factors are Entwistle and Smith (2002). They explained that each person's vital experiences will influence their development of comprehension within educational contexts and, therefore, will impact their academic results. In addition, recent research by Hughes et al. (2015) focused on the development of tools to analyse the influence of a student's social and behavioural competencies and family support.

Taking into account these approaches, we understand that the psychological and biographical factors of students influence the learning process in entrepreneurship. This learning process requires the use of different study techniques, engaging students to influence their entrepreneurial intention. Therefore, it is not only important to underline the relationship between personal factors and entrepreneurial intention, but also to study the role of the learning process. In the case of business education, which is based on the creation of skills and competencies related to entrepreneurship, these factors can also influence students to choose a professional career, which can be oriented towards entrepreneurship (Arias et al. 2015). We propose that the learning process represents an interceding factor, which is able to bridge the gaps between psychological and biographical factors, and entrepreneurial intention. Thus, we understand that only students who leverage the potential of their personal traits (psychological and biographical) to develop a learning process in effective entrepreneurship will improve their entrepreneurial intention.

In this work, entrepreneurship education refers to the learning process, considering the information provided by the course guide, students' effort and the educational process. This process focuses on fourth year students studying Entrepreneurship as part of their degree in Labour Relations and Human Resources at the University of Castilla-La Mancha. In addition, we have paid special attention to the strategic perspective, highlighting that each student will be able to acquire the best efficiency by means of activities, efforts and available time for suitable planning (Valle et al. 2003). In general, it is worth noting that the literature attaches great importance to the learning process in order to explain the reciprocal relationship between learning experience and study behaviour, and their relative impact on academic performance or entrepreneurial orientation (Hailikari and Parpala 2014). 
With this research, we expect to demonstrate that, if students are able to leverage their psychological and biographical characteristics to develop an effective learning process in entrepreneurship, they will achieve higher entrepreneurial intention. Thus, if students focus their capabilities and experiences to identify key aspects of the learning process, to use the proposed techniques efficiently and to strategically develop the process of an entrepreneurship learning system, they will achieve higher academic outcomes and entrepreneurial intention.

We base our approach on the proposition that students learn by an inner, active process of knowledge construction through their inner capacities and their own experience, and also by means of the completion of comprehension and information coming from their external reality, that is, their learning process. According to Shagrir (2015), it is precisely during the learning process that the teacher supports the student, providing them with tools and a learning system, which the student, according to our model, will have tapped in order to obtain good results. Thus, we consider that the learning process leads students to greater entrepreneurial intention through their personal factors. Therefore, we understand that inner capacities and experiences are not enough, only if students take advantage of their capacities and experiences to encourage the entrepreneurial learning process, will they be able to achieve enhanced entrepreneurial intention.

Finally, the review of the literature and the theoretical basis expounded therein led us to propose a mediating theoretical model (Figure 1). In this model, we start from the direct effects of psychological and biographical factors on students' entrepreneurial intention. However, we suggest that the effect of psychological and biographic characteristics on entrepreneurial intention will depend on the extent to which students are able to take advantage of their personal capabilities to develop an effective learning process. Thus, we propose a mediating role of the learning process to drive the psychological and biographic characteristics of the students towards entrepreneurial intention. Therefore, we can define these relationships through the following hypotheses:

Hypothesis 3. The learning process (information, student effort, educational process) mediates the relationship between psychological factors (achievement need, internal control, optimism and autonomy) and students' entrepreneurial intention.

Hypothesis 4. The learning process (information, student effort, educational process) mediates the relationship between biographical factors (age, work experience, gender and university access grades) and students' entrepreneurial intention.

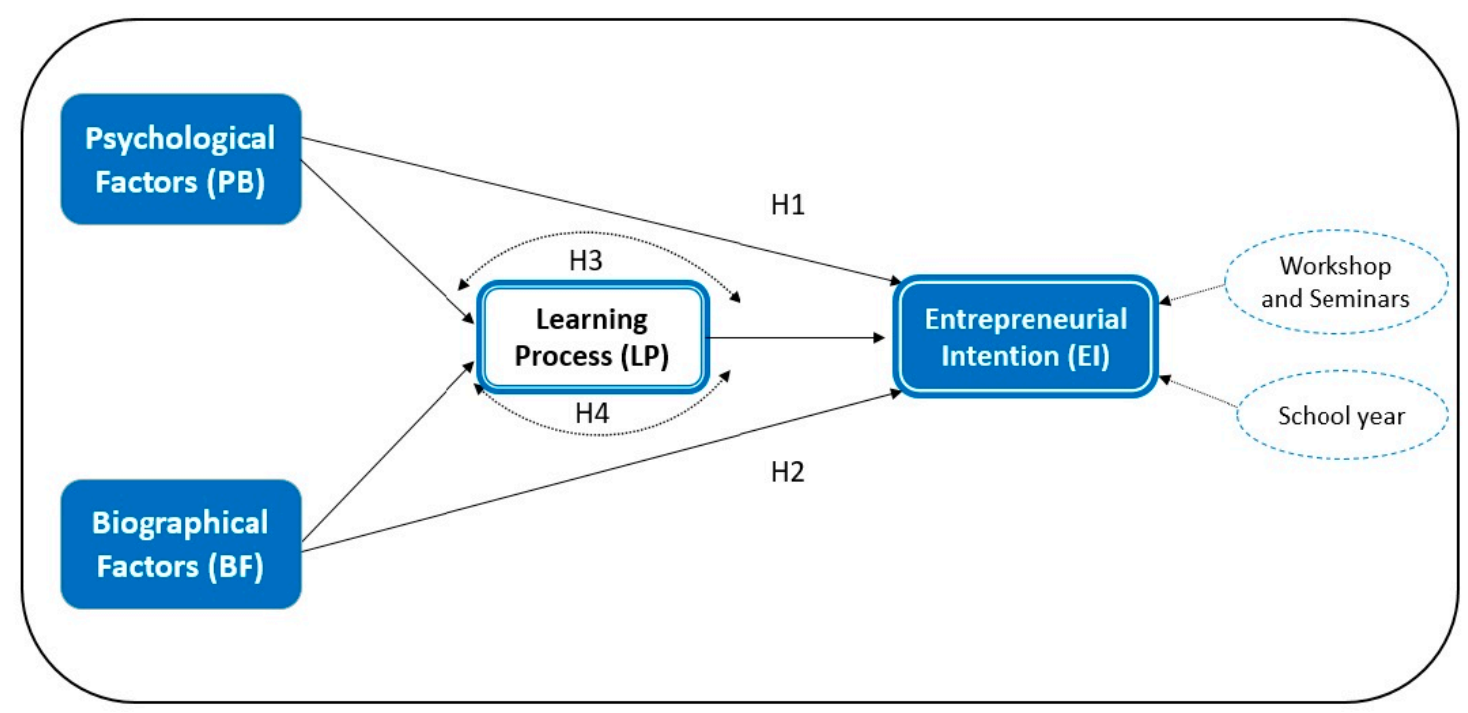

Figure 1. Proposed model and hypotheses. 


\section{Variables and Measures}

\subsection{Population and Sample}

An empirical study was conducted on students of Entrepreneurship within the Business Administration Department, studying a degree in Labour Relationships and Human Resources at the University of Castilla-La Mancha. The course is taught in the fourth year of the degree. The information was obtained for six years, from 2012/2013 to 2017/2018.

The number of students enrolled in the subject was 215. Participants ranged in age from 18 to 78. In the last class of each course, they were given a voluntary questionnaire, which was completed by 167 students (response rate of $77.67 \%$ ). This can be considered a satisfactory rate in comparison with similar surveys.

The use of a sample of university students to analyse entrepreneurial intention is common in the literature (see, among others, Ventura Fernández and Gervilla 2013; Bae et al. 2014), since students have been considered a potential population of entrepreneurs (Sánchez et al. 2005). Likewise, the sample selected is adequate to achieve the objectives of this study, since university students, when on the last year of their university education, must make a well-considered decision regarding their future, which is why an accurate picture of their intentions can be gained (De la Rosa et al. 2014).

\subsection{Context of the Entrepreneurship Course}

Having defined the sample, this section is devoted to the design of the entrepreneurship course taken by the students in the fourth year of the Labour Relations and Human Resources degree at the University of Castilla-La Mancha. The justification of this course is the need to provide students with the knowledge and skills to design and launch a business project, taking into account its feasibility, adaptation to market opportunities and its acceptability in terms of profitability, risk and ethical criteria.

As highlighted in the literature, educational institutions must design a learning process suited to the needs of students and the different industries (Keat et al. 2011). It is precisely the suitability of the learning process, that is, the teaching method, the teaching environment and the learning resources used, which will influence the students' entrepreneurial intention (Harkema and Schout 2008). For example, Ollila and Middleton (2011) consider that students should experience the creation of a new business to confront the difficulties and develop the entrepreneurial skills needed for the future. Since they are acting as entrepreneurs, they put themselves in a real situation, assuming its reality, which will allow them to grasp the difficulties and the possibilities of implementing it and, in short, to acquire the competencies related to entrepreneurship. Through this argument, the subject of entrepreneurship analysed in this paper is based mainly on the process of students creating a new business.

Table 1 shows the different learning methods used in this subject of Business Creation. As shown, the major weight and importance of the subject is the development of an assignment, with a total of $57 \mathrm{~h}$ ( $52 \mathrm{~h}$ to complete the work and $5 \mathrm{~h}$ for the oral presentation). This work consists of the fictitious creation of a new business by groups of three students. To carry this out, students receive a total of $12 \mathrm{~h}$ of theoretical classes and another $12 \mathrm{~h}$ of practical classes. First, the business plan, its stages and some recommendations are defined. Regarding the practical classes, success and failure cases are established, allowing students to make value judgments after evaluating the aspects they consider key in achieving their own success.

The first step in the project consists of the proposal of an innovative business idea with the aim of recognising commercial opportunities and developing innovative capacities. Subsequently, the students must conduct an analysis of the environment and the company, using the knowledge acquired in previous courses. Third, they must present a description of the product or service (needs satisfied, specifications and characteristics, differential values, registration of patents and brands), and a market analysis (demand and definition of the target customers). The following point lies in defining the marketing strategy (pricing policy, distribution channels, promotion strategy, brand image and positioning, sales planning, etc.). Next, they must consider the necessary infrastructures, as well 
as the logistics system (facilities, manufacturing or service process, supply of materials, inventory management) needed to implement the project. Sixth, they should consider the organization of the company and the human resources policies (organization chart, employee profiles, human and operational resources policies, labour needs and growth estimation). Seventh, they must conduct and assess a financial analysis. Finally, they have to design an action plan to create the new business.

It should be noted that throughout this process, the advances of the students are monitored by professors specialized in entrepreneurship, by means of different tutorials with the intention of guiding the process and solving the doubts that may arise. In addition, in the different tutorials and classes, the professors try to demystify the difficulties in carrying out the business project, with the aim of improving students' entrepreneurial intention. As highlighted by Robinson et al. (1991), business attitudes can be influenced by educators.

There are similarities in the methodology and temporal structure in the academic years studied. However, there are also some differences in certain activities in the process. Thus, we introduced this control variable in the learning process and entrepreneurial intention to avoid bias.

Table 1. Activities of the entrepreneurship learning process (year 4; 4.5 ECTS credits; optional).

\begin{tabular}{|c|c|c|c|c|}
\hline Educational Activity & Method & Methodology & Related Competencies ${ }^{2}$ & Hours \\
\hline Classroom teaching (Practical) & Face-to-face & Case Studies & G01, G02, G06, E07, E08, E09 & 12 \\
\hline Tutoring & Face-to-face & Directed or supervised work & G02, G03, E07, E08, E09 & 3 \\
\hline Preparing reports or papers & Autonomous & $\begin{array}{l}\text { Solving exercises and } \\
\text { problems }\end{array}$ & $\begin{array}{c}\text { G01, G02, G03, G04, G05, } \\
\text { E07, E08, E09 }\end{array}$ & 52 \\
\hline
\end{tabular}

By means of the learning process presented, we expect to achieve the following goals: To detect and evaluate entrepreneurial ideas oriented towards self-employment; to apply social research techniques to this professional field; to understand the implications of social responsibility and ethics in the decision-making process concerning a new business; to formulate and interpret the financial statements of a company; to search, analyse and summarise the information; and to present and defend a project. In sum, it can be said that, during this course, the acquisition of skills to identify and develop entrepreneurial thinking, and to launch and manage a new business, are encouraged, fulfilling the goal that every entrepreneurship course must satisfy (Raposo and do Paço 2011).

\subsection{Measurement of Variables}

The design of the questionnaire drew on a review of empirical studies, which allowed us to measure the variables analysed in different scales. In order to improve the validity of the content (Hambrick 1981), a pre-test with ten students was performed. A lengthy questionnaire was handed out, in which the students could indicate the degree of comprehensibility of the questions, as well as express their opinion as to whether the questions were appropriate for our proposed aims. Likewise, we also held discussions with academics and experts on the design of questionnaires in order that they might suggest possible criticisms and improvements. The study review, pre-test and in-depth discussions with academics and experts allowed us to draw up the final questionnaire.

We used a 5-point Likert scale to measure most of the variables. In some factors, we used dummy variables-job experience, gender and workshops and seminars-and continuous variables-age and university access grades. The variables measured are explained below and the correlations between the study variables are shown in Table 2.

2 The generic and specific competences are defined in the Appendix A. 
- Psychological variables: We used a total of 10 items to measure the psychological variables. We focused on measuring the following four psychological variables adapted from different scales: Achievement need (3 items) (McClelland et al. 1976), internal control (3 items) (Miller and Rose 1982), optimism (2 items) (Scheier et al. 1994) and autonomy (2 items) (Schwartz 1999).

- Biographical variables: We included the following biographical variables: Age, work experience, gender and university access grades.

- Learning process variables: In order to evaluate the learning process, we used three constructs: Information about the course guide (which included 5 items with information about clarity, understanding, language, content and usefulness of the information provided by the teacher in the course guide), student effort (2 items) and the educational process (which gathered 7 items providing information about materials, references, evaluation systems, planning of the subject, teaching methods and a general evaluation of the development of the subject). These scales are based on studies by Lau et al. (2008) and Román et al. (2008).

- Entrepreneurial intention: Entrepreneurial intention has been measured in different ways in the literature. One of the most widely used measures is the probability of creating a new business (Kolvereid and Moen 1997; Gutierrez and Santos 2008). Thus, in our questionnaire, as a measurement of entrepreneurial intention, we used the probability of creating one's own company in the future (1 item), measured from very unlikely (1) to very likely (5), based on an adaptation of the study by Kolvereid and Moen (1997).

- Control variables: Two control variables were used to avoid possible biases. As mentioned before, we used the academic year as a control variable since, when we obtained the questionnaires on the academic courses from 2012/2013 to 2017/2018, some activities in the learning process presented certain differences. Furthermore, the students' attendance at seminars and workshops refers to the realization of other complementary and additional courses with the objective of verifying whether the effects on entrepreneurial intention were maintained. This variable was measured following the work by Kolvereid and Moen (1997), who established attendance at other formal education activities in the field of business as a control variable for entrepreneurial education. 
Table 2. Correlations among variables.

\begin{tabular}{|c|c|c|c|c|c|c|c|c|c|c|c|c|c|}
\hline & 1 & 2 & 3 & 4 & 5 & 6 & 7 & 8 & 9 & 10 & 11 & 12 & 13 \\
\hline 1. Control & - & - & - & - & - & - & - & - & - & - & - & - & - \\
\hline 2. Achievement need & 0.450 & - & - & - & - & - & - & - & - & - & - & - & - \\
\hline 3. Autonomy & 0.260 & 0.299 & - & - & - & - & - & - & - & - & - & - & - \\
\hline 4. Optimism & 0.375 & 0.349 & 0.219 & - & - & - & - & - & - & - & - & - & - \\
\hline 5. Gender & 0.076 & 0.001 & -0.073 & -0.087 & - & - & - & - & - & - & - & - & - \\
\hline 6. Age & 0.234 & 0.338 & 0.202 & 0.192 & -0.208 & - & - & - & - & - & - & - & - \\
\hline 7. Access grades & 0.312 & 0.142 & -0.045 & 0.115 & 0.146 & 0.111 & - & - & - & - & - & - & - \\
\hline 8. Experience & -0.121 & -0.293 & -0.227 & -0.140 & 0.142 & -0.311 & -0.052 & - & - & - & - & - & - \\
\hline 9. Educational process & 0.186 & 0.196 & 0.145 & 0.360 & -0.059 & 0.187 & 0.049 & 0.035 & - & - & - & - & - \\
\hline 10. Student effort & 0.301 & 0.236 & 0.085 & 0.167 & 0.068 & 0.163 & 0.141 & -0.053 & -0.065 & - & - & - & - \\
\hline 11. Information & 0.227 & 0.264 & 0.169 & 0.152 & 0.061 & 0.092 & 0.185 & 0.008 & -0.123 & 0.433 & - & - & - \\
\hline 12. Entrepreneurial intention & 0.363 & 0.345 & 0.138 & 0.208 & -0.088 & 0.105 & 0.056 & -0.007 & -0.018 & 0.370 & 0.234 & - & - \\
\hline 13. Workshops and seminars & 0.004 & -0.119 & -0.104 & -0.126 & 0.123 & -0.321 & 0.038 & 0.008 & -0.123 & 0.433 & 0.225 & 0.357 & - \\
\hline 14. School year & 0.045 & -0.080 & -0.059 & -0.130 & 0.016 & -0.137 & -0.005 & -0.001 & 0.065 & -0.333 & -0.086 & -0.139 & -0.096 \\
\hline
\end{tabular}




\subsection{Analysis Techniques}

Structural equation analysis was used since it has certain advantages over traditional multivariate techniques (Haenlein and Kaplan 2004). Specifically, we used partial least squares (PLS) with PLS-graph software to analyse data. PLS is particularly suitable for data analysis during the early stages of theory development where the theoretical model and its measures are not definitively formed. The level of statistical significance of the coefficients of both the measurement and the structural models was determined through a bootstrap re-sampling procedure (500 subsamples). The measurement model shows that all variables have good individual reliability, composite reliability, convergent and discriminant validity. Table 3 shows the Cronbach's alpha values for all the variables, which were measured on Likert-type scales. As can be observed, all variables present a value above 0.7.

Table 3. Cronbach's alpha values for Likert-type scale variables.

\begin{tabular}{cc}
\hline Control & $\mathbf{0 . 7 8 4}$ \\
\hline Achievement need & 0.825 \\
Autonomy & 0.773 \\
Optimism & 0.875 \\
Educational process & 0.849 \\
Student effort & 0.867 \\
Information & 0.927 \\
\hline
\end{tabular}

We evaluated the structural model by examining the size and significance of the path coefficients and the $R^{2}$ values of the dependent variables.

In the hypotheses, we proposed a mediating effect of the learning process on the relationship between psychological and biographical factors and entrepreneurial intention. To confirm this, the four conditions established by Baron and Kenny (1996) must be met. For this mediator effect, the first condition requires a significant influence of the independent variables-psychological and biographical characteristics - on the dependent variable-entrepreneurial intention. The second condition establishes a relationship between the independent variables and the mediator variable-learning process. The third condition requires a relationship between the mediator variable-learning process - and the dependent variable - entrepreneurial intention. The fourth condition establishes that the relationship between the independent variables and the dependent variable should be eliminated —or at least reduced — when the mediator variables are included in the model.

As mentioned above, the aim of the study was to explore the mediating role of the learning process to explain the relationships between several psychological and biographical characteristics and entrepreneurial intention. Therefore, we include all psychological, biographical, learning process and outcome variables in the PLS graph. Subsequently, we analyse the effect of independent variables on the mediator variables and on entrepreneurial intention through the specific learning process variables.

\section{Results}

The structural model was evaluated by examining the size and significance of the path coefficients and the $\mathrm{R}^{2}$ values of the dependent variable (Table 4). 
Table 4. Results.

\begin{tabular}{|c|c|c|c|c|c|}
\hline \multirow{2}{*}{\multicolumn{2}{|c|}{ Constructs }} & \multicolumn{3}{|c|}{ Learning Process } & \multirow[t]{2}{*}{$\begin{array}{l}\text { Entrepreneurial } \\
\text { Intention }^{1}\end{array}$} \\
\hline & & Information & Educational Process & Student Effort & \\
\hline \multirow{4}{*}{ 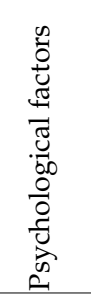 } & Achievement need & $0.151 *$ & $0.191 *$ & $0.145^{*}$ & $\begin{array}{c}0.191^{* *} \\
\left(0.268^{* * *}\right)\end{array}$ \\
\hline & Internal control & 0.081 & 0.050 & $0.175^{*}$ & $\begin{array}{c}0.246^{* *} \\
\left(0.284^{* * *}\right)\end{array}$ \\
\hline & Optimism & 0.035 & 0.085 & 0.033 & $\begin{array}{c}0.016 \\
(0.013)\end{array}$ \\
\hline & Autonomy & 0.043 & $0.132^{+}$ & 0.023 & $\begin{array}{l}-0.057 \\
(0.002) \\
\end{array}$ \\
\hline \multirow{4}{*}{ 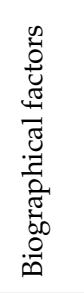 } & Age & -0.035 & 0.007 & 0.075 & $\begin{array}{c}-0.06 \\
\left(-0.055^{+}\right)\end{array}$ \\
\hline & Work experience & -0.065 & 0.029 & 0.015 & $\begin{array}{c}0.095 \\
\left(0.096^{+}\right)\end{array}$ \\
\hline & Gender & 0.034 & -0.024 & 0.070 & $\begin{array}{l}-0.129 * \\
(-0.124 *)\end{array}$ \\
\hline & $\begin{array}{l}\text { University access } \\
\text { grades }\end{array}$ & $0.146^{*}$ & -0.054 & 0.038 & $\begin{array}{l}-0.052 \\
(-0.048)\end{array}$ \\
\hline \multirow{3}{*}{$\overrightarrow{0}$} & Academic year & -0.086 & $-0.304^{* * *}$ & -0.042 & $\begin{array}{l}-0.001^{\mathrm{ns}} \\
\left(-0.114^{*}\right)\end{array}$ \\
\hline & $\begin{array}{l}\text { Workshops and } \\
\text { seminars }\end{array}$ & 0.013 & 0.030 & -0.016 & $\begin{array}{l}-0.007^{\mathrm{ns}} \\
(0.010)\end{array}$ \\
\hline & $\mathbf{R}^{2}$ & 0.106 & 0.213 & 0.124 & 0.220 \\
\hline \multirow{5}{*}{ 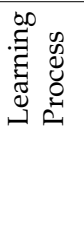 } & Information & & & & $0.145^{*}$ \\
\hline & Student effort & & & & 0.017 \\
\hline & $\begin{array}{c}\text { Educational } \\
\text { process }\end{array}$ & & & & $0.328^{* * *}$ \\
\hline & Total $\mathbf{R}^{\mathbf{L}^{2}}$ & & & & 0.361 \\
\hline & Change in $R^{2}$ & & & & $0.141^{* * *}$ \\
\hline
\end{tabular}

${ }^{+} p>0.1{ }^{*} p>0.05 ;{ }^{* *} p>0.01 ;{ }^{* * *} p>0.001{ }^{\text {ns }}$ non-significant; ${ }^{1}$ the values in parentheses represent $\beta$ without the mediator variable.

The initial results, when only the effect of biographical and psychological factors are taken into account (without the mediator variables), show that only two psychological variables influence the students' entrepreneurial orientation. Achievement need has a positive and significant effect on entrepreneurial intention $(\beta=0.268 ; p<0.001)$, and internal control also has a positive influence on entrepreneurial intention $(\beta=0.284 ; p<0.001)$. Both effects are similar in significance. With respect to biographical variables, three variables have a negative and significant effect on entrepreneurial intention: Age $(\beta=-0.055 ; p<0.1)$, work experience $(\beta=-0.096 ; p<0.1)$ and gender $(\beta=-0.124$; $p<0.05)$. In this case, the effect of gender is higher than that of the other two biographical variables. These results suggest that students with higher achievement need and internal control have greater entrepreneurial intention. Furthermore, younger students, students with more work experience and male students have greater entrepreneurial intention. The $R^{2}$ of this model is 0.220 . These results allow us to accept Hypotheses 1 and 2.

With the mediator variable, the learning process, included in the model, it can be observed that student information $(\beta=0.145 ; p<0.05)$ and, primarily, the educational process $(\beta=0.328 ; p<0.001)$ have a significant and positive effect on entrepreneurial intention. The $R^{2}$ result of this model is 0.361 . In this line, it can be observed that this model improves the previous one because the addition of the learning process significantly increases the $R^{2}$ (from 0.222 to 0.361 ), with an increment of 0.141 in significance at $p<0.001$. Thus, it can be said that the learning process is an important mechanism to explain entrepreneurial orientation.

Analysing the mediating role of the learning process variables, only achievement need affects the three components of the learning process. Furthermore, as previously stated, the learning process influences entrepreneurial intention. Finally, it can be observed in Table 4 that when we consider the 
dependent, independent and mediator variables in the same model, the initial effect of achievement need on entrepreneurial intention is reduced (specifically information and the educational process) through the learning process. Thus, these results show a partial mediating effect between achievement need and entrepreneurial intention through two variables of the learning process-information and educational process. Thus, the detection of a partial mediator effect of the psychological factors on entrepreneurial intention, such as achievement need, allows us to partially accept Hypothesis 3.

Finally, we can observe that biographical factors have no effect on the learning process. Our results show no mediating effect of the biographical variables on entrepreneurial intention through the learning process. Therefore, Hypothesis 4 cannot be accepted.

Table 5 shows the principal significant effects.

Table 5. Direct, indirect and total effects on entrepreneurial intention.

\begin{tabular}{cccc}
\hline & Direct & Indirect & Total \\
\hline Internal control & 0.246 & - & 0.246 \\
Gender & -0.129 & - & -0.129 \\
Information & 0.145 & & 0.145 \\
Educational process & 0.328 & & 0.328 \\
Achievement need through educational process & 0.191 & 0.063 & 0.254 \\
Achievement through information & 0.151 & 0.022 & 0.173 \\
\hline
\end{tabular}

\section{Discussion}

Achievement need is a key psychological characteristic in explaining entrepreneurial intention. The students with higher achievement need are those who improve their entrepreneurial intention. However, the potential of students with achievement need to obtain high entrepreneurial intention will only be realized if they follow a suitable learning process. Internal control also determines the improvement of entrepreneurial intention. Autonomy is not a key psychological characteristic in improving students' entrepreneurial intention. Thus, we find that the learning process represents an interceding factor, which is able to bridge the gaps between the psychological factors and entrepreneurial intention. Therefore, the results obtained with respect to the influence of achievement need and internal control on entrepreneurial intention are in agreement with the proposed hypotheses. These factors have been highlighted in the entrepreneurship literature due to their strong relationship with entrepreneurial motivation when confronting the uncertainty of the business creation process (Barba-Sánchez and Atienza-Sahuquillo 2018). In contrast, the results concerning autonomy and optimism are not in agreement with the hypothesis, since the influence of these psychological factors is mainly manifested through work experience, which most students lack, and they could thus focus on other professional orientations.

Certain biographical factors, such as age, work experience and gender, have a significant direct effect on entrepreneurial intention. Specifically, it is observed that younger people with previous work experience and men have greater entrepreneurial intention, coinciding with other studies. However, no empirical evidence was found regarding university access grades, which may lead to other professional orientations. Likewise, we can observe that the learning process does not mediate between the biographical characteristics of individuals and their entrepreneurial intention.

\section{Conclusions and Implications}

The results provide important theoretical and practical contributions for the study of the background to entrepreneurial intention. First, following the previous literature (De Pillis and Reardon 2007; Kautonen and Palmroos 2010), this study offers a better understanding of determinants of entrepreneurial intention, helping to fill this gap in the literature. Second, another theoretical contribution is that we provide new evidence about one of the key predictors of entrepreneurship, namely entrepreneurial intention (Kautonen et al. 2015). In this sense, an integrated approach to an 
in-depth understanding of the key role of the learning process is proposed in order to help explain how to improve students' entrepreneurial intention. Third, an empirical contribution to the role of the learning process is shown, taking into account the relationship between student characteristics and entrepreneurial intention. Fourth, in line with the previous literature, our results support the role of the learning process (Hailikari and Parpala 2014). Thus, we have found that the effect of students' characteristics-mainly psychological aspects—on their entrepreneurial intention depends on the extent to which students are able to leverage their personal capabilities to develop an effective learning process.

Among the practical implications, the results of the study can provide recommendations for students, teachers and academic institutions. Students can learn how to take advantage of their psychological capabilities together with academic and work experience in order to adopt the most suitable learning process to improve their entrepreneurial intention. In sum, students should develop a learning process in effective entrepreneurship.

In addition, teachers will find evidence that will help them adapt the learning process to the specific psychological and biographical characteristics of each student, so as to improve their skills and so develop better entrepreneurial intention. In this sense, according to Barba-Sánchez and Atienza-Sahuquillo (2018), it would be advisable for teachers to develop idea-generation workshops or inter-university business-plan competitions to promote entrepreneurial skills and link them with the learning process. These results can also have implications for academic managers and academic authorities. In this sense, academic authorities should develop programs with a view to promoting more effective learning processes. Thus, they would promote entrepreneurial intention, and as a consequence, they would be able to contribute to economic growth and employment generation in their community.

\section{Limitations and Future Lines of Research}

This work is not exempt from limitations. Our research has focused on certain psychological traits (achievement need, internal control, optimism and autonomy) and biographical characteristics (age, work experience, gender and university access grades) of the students under study to analyse their influence on entrepreneurial intention. However, the wide range of exogenous environmental factors (political, economic, demographic and technological) that may influence entrepreneurial intention have not been taken into account. As Fatoki (2010) established, personality and biographical traits are linked to contextual ones. This limitation is useful to propose, as a line of future research, the incorporation of an integrated model that includes internal and exogenous factors to improve the understanding of the antecedents of entrepreneurial intention. On the other hand, entrepreneurial intention represents the best predictor of a person's commitment to becoming an entrepreneur in the future (Kautonen et al. 2015). However, intention is a necessary aspect, but not sufficient alone to becoming an entrepreneur. This is why some authors (e.g., Roth and Lacoa 2009) have recommended a longitudinal study to verify how many students with entrepreneurial intention really create a new business. Similarly, few studies have addressed the evolution of entrepreneurial intention before and after completing an entrepreneurship course, so it is recommended to analyse these results at the beginning and the end of the entrepreneurial learning process, as already stated by Azanza and Campos (2014). Furthermore, we propose to include other students' characteristics, such us the jobs and entrepreneurial experience of parents, other family members or friends, courses passed, external control locus, empathy, emotional intelligence, among other things, in a binary logistic model of entrepreneurial intention.

Another limitation is that the study only shows a partial model to explain entrepreneurial intention. In this sense, a new proposal for the development of future research is to expand the information on both the mediating and moderating roles of the learning process to help explain entrepreneurial intention. Another proposal might be the analysis of how students' characteristics and the learning process affect other professional orientations. Finally, our sample only consisted of students from one Spanish university, and thus the results obtained might vary in other countries, 
or even according to the degree course in which the entrepreneurship course is delivered. Therefore, we propose to replicate this study in other countries and degrees in order to compare and contrast the results, while increasing the understanding of the antecedents of entrepreneurial intention.

Author Contributions: Conceptualization, Mateo M. Córcoles-Muñoz, Pedro M. García-Villaverde, Francisco J. Ramirez-Fernández, Gloria Parra-Requena and Maria J. Ruiz-Ortega; methodology, Gloria Parra-Requena and Pedro M. García-Villaverde; review and editing, Maria J. Ruiz-Ortega and Francisco J. Ramirez-Fernández.

Funding: This research was funded by the Ministry of Economy, Industry and Competitiveness of Spain (Project: ECO2016-75781-P AEI/FEDER, UE) and also by the Ministry of Education, Culture and Sport for the Training Program of University Teachers (ID: FP 17/853).

Conflicts of Interest: The authors declare no conflict of interest.

\section{Appendix A}

\section{General Competencies:}

\begin{tabular}{cl}
\hline G01: & $\begin{array}{l}\text { Ability to search, analyse and summarise information to build arguments and make } \\
\text { judgments in the different areas of performance. }\end{array}$ \\
\hline G02: & $\begin{array}{l}\text { Ability to present and defend orally and /or in writing matters or issues related to } \\
\text { their specialty. }\end{array}$ \\
\hline G03: & $\begin{array}{l}\text { Capacity for continuous, self-directed and autonomous learning, allowing students to develop } \\
\text { learning skills necessary to undertake further study with a high degree of autonomy. }\end{array}$ \\
\hline G04: & Ability to adequately use ICT in the different areas of performance. \\
\hline G05: & $\begin{array}{l}\text { Ability to understand general information in a foreign language, employing frequently } \\
\text { used expressions. }\end{array}$ \\
\hline G06: & $\begin{array}{l}\text { Ability to develop professional activities in accordance with ethical principles and respect for } \\
\text { fundamental rights. }\end{array}$ \\
\hline
\end{tabular}

Specific Competencies:

\begin{tabular}{cl}
\hline E06: & $\begin{array}{l}\text { Knowledge of the theories and fundamentals of business organization and business } \\
\text { management from structural and behavioural perspectives, to ensure effective and efficient } \\
\text { operation, paying attention to the human aspects of organizations. }\end{array}$ \\
\hline E07: & $\begin{array}{l}\text { Ability to fully understand the behavioural approaches of people the organization, } \\
\text { management of work and human resource management }\end{array}$ \\
\hline E08: & $\begin{array}{l}\text { Capacity for analysis and diagnosis, support and decision-making regarding organizational } \\
\text { structure, work organization, working method studies and working time studies. }\end{array}$ \\
\hline E09: & $\begin{array}{l}\text { Ability to participate in the development and design of human resources strategies, } \\
\text { integrating people into the organization's overall strategy. }\end{array}$ \\
\hline E10: & $\begin{array}{l}\text { Ability to apply management techniques and motivational groups to improve the } \\
\text { working environment. }\end{array}$ \\
\hline
\end{tabular}

\section{References}

Ajzen, Icek. 1987. Attitudes, traits and actions: Dispositional prediction of behaviour in personality and social psychology. Advances in Experimental Social Psychology 20: 1-63.

Ajzen, Icek. 1991. The theory of planned behaviour. Organizational and Human Decision Processes 50: 179-211. [CrossRef]

Altinay, Levent, Melih Madanoglu, Roberto Daniele, and Conrad Lashley. 2012. The influence of family tradition and psychological traits on entrepreneurial intention. International Journal of Hospitality Management 31: 489-99. [CrossRef] 
Antonioli, Davide, Francesco Nicolli, Laura Ramaciotti, and Ugo Rizzo. 2016. The effect of intrinsic and extrinsic motivations on academics' entrepreneurial intention. Administrative Sciences 6: 15. [CrossRef]

Arias, A.V., I.M. Restrepo, and A. M. Restrepo. 2015. Factores explicativos de las intenciones emprendedoras en estudiantes universitarios. Espacios 36: 1-15.

Ashford, Susan J., and J. Stewart Black. 1996. Proactivity During Organizational Entry: The Role of Desire for Control. Journal of Applied Psychology 81: 199-214. [CrossRef]

Ashley-Cotleur, Catherine, Sandra King, and George Solomon. 2009. Parental and Gender Influences on Entrepreneurial Intentions, Motivations and Attitudes. Washington: George Washington University.

Auken, Howard Van. 2013. Influence of a culture-based entrepreneurship program on student interest in business ownership. International Entrepreneurship and Management Journal 9: 261-72. [CrossRef]

Azanza, Garazi, and José A. Campos. 2014. La intención emprendedora en estudiantes universitarios. El caso de la Universidad de Deusto. Boletín de Estudios Económicos 211: 151-72.

Bae, Tae Jun, Shanshan Qian, Chao Miao, and James O. Fiet. 2014. The Relationship between entrepreneurship education and entrepreneurial intentions: A Meta-Analytic Review. Entrepreneurship Theory and Practice 38: 217-54. [CrossRef]

Barba-Sánchez, Virginia, and Carlos Atienza-Sahuquillo. 2017. Entrepreneurial motivation andself-employment: Evidence from expectancy theory. International Entrepreneurship and Management Journal 13: 1097-115. [CrossRef]

Barba-Sánchez, Virginia, and Carlos Atienza-Sahuquillo. 2018. Entrepreneurial intention among engineering students: The role of entrepreneurship education. European Research on Management and Business Economics 24: 53-61. [CrossRef]

Baron, Reuben M., and David A. Kenny. 1996. The moderator-mediator variable distinction in social psychological research: conceptual, strategic and statistical considerations. Journal of Personality and Social Psychology 51: 1173-82. [CrossRef]

Brito, Pino, Alicia Cruz, and Ana I. Hernández. 2014. Un paso más en la investigación de la intención emprendedora del estudiante universitario: GUESSS. Revista de Estudios Empresariales Segunda Época 2: 63-80.

Brückner, Sebastian, Manuel Förster, Olga Zlatkin-Troitschanskaia, and William B. Walstad. 2015. Effects of prior economic education, native language, and gender on economic knowledge of first-year students in higher education. A comparative study between Germany and the USA. Studies in Higher Education 40: 437-53. [CrossRef]

Carlsson, Bo, Pontus Braunerhjelm, Maureen McKelvey, Christer Olofsson, Lars Persson, and Håkan Ylinenpää. 2013. The evolving domain of entrepreneurship research. Small Business Economics 41: 913-30. [CrossRef]

Carsrud, Alan L., and Malin Brännback. 2009. Understanding the Entrepreneurial Mind: Opening the Black Box. Berlin: Springer Science \& Business Media.

Ciavarella, Mark A., Ann K. Buchholtzb, Christine M. Riordanb, Robert D. Gatewoodb, and Garnett S. Stokesc. 2004. The big five and venture survival: Is there a linkage? Journal of Business Venturing 19: 465-83. [CrossRef]

Davidsson, Per. 1995. Determinants of Entrepreneurial Intentions. Paper presented at RENT XI Workshop, Piacenza, Italy, November 23-24.

De la Rosa, Carmen I., Francisco Rodríguez, and Naira Rodríguez. 2014. Condicionantes de la intención emprendedora en el alumnado universitario: un análisis desde la perspectiva de género. Revista de Estudios Empresariales. Segunda Época 2: 81-96.

De Pillis, Emmeline, and Kathleen K. Reardon. 2007. The influence of personality traits and persuasive messages on entrepreneurial intention: A cross-cultural comparison. Career Development International 12: 382-96. [CrossRef]

Entwistle, Noel, and Colin A. Smith. 2002. Personal understanding and target understanding: Mapping influences on the outcomes of learning. British Journal of Educational Psychology 72: 321-42. [CrossRef]

Espíritu Olmos, Roberto. 2011. Análisis de la intención emprendedora en estudiantes universitarios a través de los rasgos de personalidad. Multiciencias 11: 65-75.

Espiritu-Olmos, Roberto, and Miguel A. Sastre-Castillo. 2015. Personality traits versus work values: Comparing psychological theories on entrepreneurial intention. Journal of Business Research 68: 1595-98. [CrossRef]

Fatoki, Olawale Olufunso. 2010. Graduate entrepreneurial intention in South Africa: Motivations and obstacles. International Journal of Business and Management 5: 87-98. 
Fayolle, Alain, and Benoit Gailly. 2013. The Impact of Entrepreneurship Education on Entrepreneurial Attitudes and Intentions: Hysteresis and Persistence. Journal of Small Business Management 53: 75-93. [CrossRef]

Fine-Davis, Margret, and Daniel Faas. 2014. Equality and diversity in the classroom: Acomparison of students' and teachers' attitudes in six European countries. Social Indicators Research 119: 1319-34. [CrossRef]

Fishbein, Martin, and Icek Ajzen. 1975. Belief, Attitude, Intention and Behavior: An Introduction Theory and Research. Reading: Addison Wesley.

Freire, María Teresa. 2015. Educación en emprendimiento. Revisión de la literatura económica. Iberian Journal of the History of Economic Thought 2: 82-100. [CrossRef]

Gatewood, Elizabeth J., Kelly G. Shaver, and William B. Gartner. 1995. A longitudinal study of cognitive factors influencing start-up behaviors and success at venture creation. Journal of Business Venturing 10: 371-91. [CrossRef]

Gibbs, R.W. 2004. Intentions in The Experience of Meaning. Cambridge: Cambridge University Press.

Gómez-Gras, Jose Maria, Ignacio Mira Solves, and Jesus Martinez Mateo. 2010. Determinants ofthe entrepreneurship: An overview perspective. International Journal of Business Environment 3: 1-14. [CrossRef]

González, Norma, and José L. Valdez. 2012. Optimismo-pesimismo y resiliencia en adolescentes de una universidad pública. CIENCIA ergo sum 19: 207-214.

González Moreno, Ángela, Llanos López Muñoz, and Rosario Pérez Morote. 2019. The Role of Higher Education in Development of Entrepreneurial Competencies: Some Insights from Castilla-La Mancha University in Spain. Administrative Sciences 9: 16. [CrossRef]

Gutierrez, María J., and Francisco J. Santos. 2008. La actividad emprendedora de las mujeres y el proceso de creación de empresas. Información Comercial Española 841: 117-32.

Haenlein, Michael, and Andreas M. Kaplan. 2004. A beginner's guide to partial least squares analysis. Understanding Statistics 3: 283-97. [CrossRef]

Hailikari, Telle Katriina, and Anna Parpala. 2014. What impedes or enhances my studying? The interrelation between approaches to learning, factors influencing study progress and earned credits. Teaching in Higher Education 19: 812-24. [CrossRef]

Hambrick, Donald C. 1981. Environment, strategy and power within top management teams. Administrative Science Quarterly 26: 253-75. [CrossRef]

Happ, Roland, Olga Zlatkin-Troitschanskaia, and Susanne Schmidt. 2016. An analysis of economic learning among undergraduates in introductory economics courses in Germany. The Journal of Economic Education 47: 300-10. [CrossRef]

Harkema, Saskia, and Henk Schout. 2008. Incorporating student-centred learning in innovation and entrepreneurship education. European Journal of Education 43: 513-26. [CrossRef]

Harris, Michael L., Shanan G. Gibson, and Sherrill R. Taylor. 2007. Examining the impact of small business institute participation on entrepreneurial attitudes. Journal of Small Business Strategy 18: 57-75.

Hatak, Isabella, Rainer Harms, and Matthias Fink. 2015. Age, job identification, and entrepreneurial intention. Journal of Managerial Psychology 30: 38-53. [CrossRef]

Henley, Andrew. 2007. Entrepreneurial aspiration and transition into self-employment: Evidence from British longitudinal data. Entrepreneurship and Regional Development 19: 253-80. [CrossRef]

Hessels, Jolanda, Marco van Gelderen, and Roy Thurik. 2008. Entrepreneurial aspirations, motivations, and their drivers. Small Business Economics 31: 323-39. [CrossRef]

Hughes, Claire, Irenee Daly, Sarah Foley, Naomi White, and Rory T. Devine. 2015. Measuring the foundations of school readiness: Introducing a new questionnaire for teachers-The Brief Early Skills and Support Index (BESSI). British Journal of Educational Psychology 85: 332-56. [CrossRef]

Ilouga, S. Nyock, A. C. Nyock Mouloungni, and Jean-Michel Sahut. 2014. Entrepreneurial intention and career choices: The role of volition. Small Business Economics 42: 717-28. [CrossRef]

INE. 2018. Directorio Central de Empresas de 2016. Madrid: Instituto Nacional de Estadística, Available online: www.ipyme.org/es-ES/ApWeb/EstadisticasPYME/.../CifrasPYME-enero2018.pdf (accessed on 8 February 2019).

Kautonen, Teemu, and Jenni Palmroos. 2010. The impact of a necessity-based start-up on subsequent entrepreneurial satisfaction. International Entrepreneurship and Management Journal 6: 285-300. [CrossRef] 
Kautonen, Teemu, Marco van Gelderen, and Matthias Fink. 2015. Robustness of the theory of planned behavior in predicting entrepreneurial intentions and actions. Entrepreneurship, Theory and Practice 39: 655-74. [CrossRef]

Keat, Yeng Keat, Christopher Selvarajah, and Denny Meyer. 2011. Inclination towards entrepreneurship among university students: an empirical study of Malaysian university students. International Journal of Business and Social Science 2: 206-20.

Kolvereid, Lars, and Øystein Moen. 1997. Entrepreneurship among business graduates: does a major in entrepreneurship make a difference? Journal of European Industrial Training 21: 154-60. [CrossRef]

Krueger, Norris F., and Deborah V. Brazeal. 1994. Entrepreneurial Potential and Potential Entrepreneurs. Entrepreneurship Theory and Practice 18: 91-104. [CrossRef]

Kuttim, Merle, Marianne Kallaste, Urve Venesaar, and Aino Kiis. 2014. Entrepreneurship Education at University Level and Students' Entrepreneurial Intentions. Procedia-Social and Behavioral Sciences 110: 658-68. [CrossRef]

Lau, Shun A., Gregory Arief D. Liem, and Youyan Nie. 2008. Task- and self-related pathways to deep learning: The mediating role of achievement goals, classroom attentiveness, and group participation. British Journal of Educational Psychology 78: 639-62. [CrossRef] [PubMed]

Lee, Soo Hoon, and Poh Kam Wong. 2004. An exploratory study of technoempreneurial intentions: A carree anchor perspective. Journal of Business Venturing 19: 7-28. [CrossRef]

Lima, Edmilson, Rose M. Lopes, Vânia Nassif, and Dirceu da Silva. 2015. Opportunities to Improve Entrepreneurship Education: Contributions Considering Brazilian Challenges. Journal of Small Business Management 53: 1033-51. [CrossRef]

Liñan, Francisco, and Alain Fayolle. 2015. A systematic literature review on entrepreneurial intentions: Citation, thematic analyses, and research agenda. International Entrepreneurship and Management Journal 11: 907-33. [CrossRef]

Liñán, Francisco, Juan Carlos Rodríguez-Cohard, and José M. Rueda-Cantuche. 2011. Factors affecting entrepreneurial intention levels: A role for education. International Entrepreneurship and Management Journal 7: 195-218. [CrossRef]

Loli, Alejandro, Edwin T. Dextre, Javier Del Carpio, and Elsa La Jara. 2010. Actitudes de creatividad y emprendimiento en estudiantes de la Universidad Nacional de Ingeniería y su relación con algunas variables socio demográficas. Revista de Investigación en Psicología 13: 139-51. [CrossRef]

Lorz, Michael, Susan Müller, and Thierry Volery. 2011. Entrepreneurship Education: A Meta- Analysis of Impact Studies and Applied Methodologies. Paper presented at FGF G-Forum, Zurich, Switzerland, November 4.

Mai, Ngoc, and Pham Anh. 2013. Factors affecting small enterprises in Vietnam. International Journal of Business and Social Science 5: 53-62.

Martínez, Ana M., and Monica Milone. 2016. El emprendimiento en España: Intención emprendedora, motivaciones y obstáculos. Journal of Globalization, Competitiveness \& Governability/Revista de Globalización, Competitividad y Gobernabilidad/Revista de Globalização, Competitividade e Governabilidade 10: 95-109.

Marulanda, Jorge A., Geovanny Correa, and Luís F. Mejía. 2009. Emprendimiento: Visiones desde las teorías del comportamiento humano. Revista Escuela de Administración de Negocios 66: 153-68. [CrossRef]

Mazzarol, Tim, Thierry Volery, Noelle Doss, and Vicki Thein. 1999. Factors influencing small business start-ups, a comparison with previous research. International Journal of Entrepreneurial Behaviour and Research 5: 48-63. [CrossRef]

McClelland, David C. 1961. The Achieving Society. Van Nostrand: Free Press.

McClelland, David C., John W. Atkinson, Russell A. Clark, and Edgar L. Lowell. 1976. The Achievement Motive. Oxford: John Wiley \& Sons Inc.

Miller, Judy Z., and Richard J. Rose. 1982. Familial resemblance in locus of control: A twin-family study of the internal-external scale. Journal of Personality and Social Psychology 42: 535. [CrossRef]

Mokhtar, Mokhtar, and Yuserrie Zainuddin. 2011. Entrepreneurial intention of accounting students in Malaysian polytechnics institutions: A theory of planned behavior approach. Paper presented at Proceedings of Global Business and Social Science Research Conference, Beijing, China, June 21.

Mueller, Susan. 2011. Increasing entrepreneurial intention: Effective entrepreneur-ship course characteristics. International Journal of Entrepreneurship and Small Business 13: 55-74. [CrossRef] 
Musteen, Martina, Ross Curran, Nuno Arroteia, Maria Ripollés, and Andreu Blesa. 2018. A Community of Practice Approach to Teaching International Entrepreneurship. Administrative Sciences 8: 56. [CrossRef]

Obschonka, Martin, Rainer K. Silbereisen, and Eva Rodermund. 2010. Entrepreneurial intention as developmental outcome. Journal of Vocational Behavior 77: 63-72. [CrossRef]

Ollila, Susanne, and Karen Williams Middleton. 2011. The venture creation approach: integrating entrepreneurial education and incubation at the university. International Journal of Entrepreneurship and Innovation Management 13: 61-178. [CrossRef]

Oosterbeek, Hessel, Mirjam van Praag, and Auke Ijsselstein. 2010. The impact of entrepreneurship education on entrepreneurship skills and motivation. European Economic Review 54: 442-54. [CrossRef]

Perera, Harsha N., Peter McIlveen, and Mark E. Oliver. 2015. The mediating roles of coping and adjustment in the relationship between personality and academic achievement. British Journal of Educational Psychology 85: 440-57. [CrossRef]

Phipps, Simone T. A., and Leon C. Prieto. 2015. Women versus men in entrepreneurship: a comparison of the sexes on creativity, political skill, and entrepreneurial intentions. Academy of Entrepreneurship Journal 21: 32-43.

Pintrich, Paul R. 1994. Continuities and discontinuities: Future directions for research in educational psychology. Educational Psychologist 29: 137-48. [CrossRef]

Prodan, Igor, and Mateja Drnovsek. 2010. Conceptualizing academic-entrepreneurial intentions: An empirical test. Technovation 30: 332-47. [CrossRef]

Raposo, Mário M., and Arminda A. do Paço. 2011. Entrepreneurship education: relationship between education and entrepreneurial activity. Psicothema 23: 453-57.

Richter, Ingrid. 1998. Individual and Organizational Learning at the Executive Level. Management Learning 29: 299-316. [CrossRef]

Robinson, Peter B., David V. Stimpson, Jonathan C. Huefner, and H. Keith Hunt. 1991. An Attitude Approach to the Prediction of Entrepreneurship. Entrepreneurship: Theory \& Practice 15: 13-31.

Román, Sergio, Pedro J. Cuestas, and Pedro Fenollar. 2008. An examination of the interrelationships between self-esteem, others' expectations, family support, learning approaches and academic achievement. Studies in Higher Education 33: 127-38. [CrossRef]

Roth, Eric, and Devadip Lacoa. 2009. Análisis psicológico del emprendimiento en estudiantes universitarios: medición, relaciones y predicción. Ajayu 7: 2-38.

Sánchez, José Carlos, Ana Lanero, and Amaia Yurrebaso. 2005. Variables determinantes de la intención emprendedora en el contexto universitario (Determinant Variables of the Entrepreneurial Intention in the University Context). Revista de Psicología Social Aplicada 15: 37-60.

Scheier, Michael F., Charles S. Carver, and Michael W. Bridges. 1994. Distinguishing optimism from neuroticism (and trait anxiety, self-mastery, and self-esteem): a reevaluation of the Life Orientation Test. Journal of Personality and Social Psychology 67: 1063-78. [CrossRef] [PubMed]

Schunk, D.H., and F. Pajares. 2004. Self-efficacy in education revisited: Empirical and applied evidence. Big Theories Revisited 4: 115-38.

Schwartz, Shalom H. 1999. A theory of cultural values and some implications for work. Applied Psychology 48: 23-47. [CrossRef]

Shagrir, Leah. 2015. Working with students in higher education-Professional conceptions of teacher educators. Teaching in Higher Education 20: 783-94. [CrossRef]

Shane, Scott, and S. Venkataraman. 2000. The promise of entrepreneurship as a field of research. Academy of Management Review 25: 217-26. [CrossRef]

Soomro, Bahadur Ali, and Naimatullah Shah. 2015. Developing attitudes and intentions among potential entrepreneurs. Journal of Enterprise Information Management 28: 304-22. [CrossRef]

Toledo-Nickels, Ulises. 2001. Ejercicio de Construcción de un ideal-tipo de la vida social. El caso del emprendedor. Cinta de Moebio 12: 48-68.

Türker, Duygu, and Senem Sonmez. 2009. Which factors affect entrepreneurial intention of university students? Journal of European Industrial Training 33: 142-59. [CrossRef]

Urbano, David, and Sebastian Aparicio. 2015. Entrepreneurship capital types and economic growth: International evidence. Technological Forecasting and Social Change 102: 32-44. [CrossRef] 
Valle, Antonio, Ramón G. Cabanach, José C. Núñez, Julio González-Pienda, Susana Rodríguez, and Isabel Piñeiro. 2003. Cognitive, motivational and volitional dimensions of learning: An empirical test of a hypothetical model. Research in Higher Education 44: 557-80. [CrossRef]

Van Gelderen, Marco, Maryse Brand, Mirjam van Praag, Wynand Bodewes, Erik Poutsma, and Anita van Gils. 2008. Explaining entrepreneurial intentions by means of the theory of planned behaviour. Career Development International 13: 538-59. [CrossRef]

Ventura Fernández, Rafael, and María José Quero Gervilla. 2013. Factores explicativos de la intención de emprender en la mujer. Aspectos diferenciales en la población universitaria según la variable género. Cuadernos de Gestión 13: 127-49. [CrossRef]

Verheul, Ingrid, Peter van der Zwan, Roy Thurik, and Jolanda Hessels. 2016. Factors Influencing the Entrepreneurial Engagement of Opportunity and Necessity Entrepreneurs. Eurasian Business Review 6: 273-95.

(C) 2019 by the authors. Licensee MDPI, Basel, Switzerland. This article is an open access article distributed under the terms and conditions of the Creative Commons Attribution (CC BY) license (http://creativecommons.org/licenses/by/4.0/). 